\title{
EXPLORING CONSTRUCTIVIST TASK MOTIVATION OF ENGLISH L2 ACQUISITION GRADUATE STUDENTS THROUGH LEARNING MATERIALS
}

\section{J. Ngoepe}

Department of Languages

University of Limpopo

Sovenga, South Africa

e-mail: junia.ngoepe@gmail.com

\section{ABSTRACT}

English Second Language Acquisition (ESLA) students need relatively more support from their learning environment. This essential support could be in the form of task motivation through L2 materials in their academic endeavour to create knowledge among the English language community mainly consisting of peers and lecturers. In a bid to motivate students to perform planned tasks which eventually lead them to participating in language learning, of their own volition, the lecturer is cognisant of students' Individual Differences (IDs) and links this to Dynamic Systems (DS) which do play a role in the ESLA process. The researcher motivated ESLA graduate students to perform tasks through L2 materials.

Key words: graduate, English, discipline, community, second language, acquisition, task, motivation, agency, dynamic, systems

\section{INTRODUCTION}

Motivating English Second Language Acquisition (ESLA) students to perform tasks through Second Language (L2) materials can, to a great extent, be factored in and sustained through students' agency to participate in course activities, locus of causality and locus of control through L2 materials as they create knowledge in their different pre-assigned roles they play in the English discipline community. The use of Dynamic Systems Approach (DSA) helps acknowledge students' Individual Differences (IDs) as well as sustain their essential interactions with the English language community. This article aims to discuss how University of Limpopo (UL) cohorts of ESLA graduate students were motivated to perform tasks through L2 materials over a three year period.

\section{TASK-BASED LEARNING}

Tasks are central to Second Language Acquisition (SLA) research and in language pedagogy (cf. Ngoepe 2017, 174). They also afford the researcher an opportunity to manipulate learners' 
interactions, the kind of interactional feedback received, and the kind of output produced (Mackey 2012, 22). Similarly, tasks allow the lecturer to manipulate students' interactions in the SLA course. Tasks in the form of seminar oral presentations, hold a central place in SLA sessions (see Appendix A).

Nunan $(1991,2004)$ states that Task-based Language Learning (TBLL) is a sub-category of Communicative Language Teaching (CLT). Further, Christison and Murray $(2014,202)$ argue that the emergence of TBLL was one of the major developments in language teaching and learning which came about in the 1980s. This is also known as Task-based Language Teaching (TBLT) or Task-based Instruction (TBI). This came about together with the popularisation of CLT.

Task-based Learning (TBL) is an approach which depends on learner interaction. The rationale for using TBL is that students would have more opportunities to interact among themselves because interaction and output are essential components in facilitating language acquisition (Tasseron 2015, 22). Similarly, SLA students have opportunities to interact with one another. Thus, interaction may be positively influenced by affective learner modes such as motivation (McDonough, Shaw and Masuhara 2013, 239). These students are also motivated to participate in the ESLA course activities.

Ellis $(2011,223)$ likens tasks to pedagogical materials. Therefore, tasks are the operationalization of such materials. Tasseron $(2015,27)$ argues that the efficacy of the materials could be attributed to their TBL theoretical underpinnings, and the suitability of the learning context in which they are used. As ESLA students carry out tasks, they operationalise learning materials.

If lecturers can harness students' interests and apply them pedagogically, the extent to which students are interested in certain topics or tasks can be improved; this is linked to intrinsic motivation (Abu-Rabia 2003, 348). Thus, the course lecturer aims to harness graduate students' interests and apply them to SLA learning.

Intrinsic motivation is normally boosted by culturally familiar content. For example, if the materials students are exposed to serve the dual goals of being friendly in a South African way and cater for the culture of the classroom (cf. Tomlinson and Masuhara 2004, 19). In their illustrations during oral and written presentations, students often adapt the materials they use to a culturally relevant South African context.

Tasks may be categorized and grouped based on almost any prominent feature of tasks. The most common and most often used way of categorizing tasks is according to the four main language skills; listening, speaking, reading and writing. Teachers and curriculum designers ought to always keep the development of the four skills in mind when they plan for and select 
tasks (Christison and Murray 2014, 203). The tasks SLA course students are expected to perform are mainly in the form of oral and written presentation.

In line with the above, SLA post-graduate sessions attempt to develop the following main language skills: listening (of non-presenting students who constitute an audience), reading (as they prepare for oral and written presentations), speaking (students scheduled to present and those engaging the presenters) and writing (when they prepare PowerPoint slides of their oral presentations and written assignments. Pica $(2005,439)$ argues that in this way, language practitioners will recognise that L2 classrooms can become centres for purposeful communication and exchanges carrying meaning.

Of primary concern in TBLL, however, is how lecturers select tasks and decide to implement them. There must also be a system for task implementation that allows for a focus on language and meets communicative needs (Christison and Murray 2014, 205; see Appendix A). The researcher selects different tasks emanating from SLA pertinent themes and include them in the course outline.

Although not for beginners, a task-based activity tends to be student-centered because learners have more freedom in learning as they are exposed to more as well as varied input (Christison and Murray 2014, 207; see Task Review).

\section{PROCEDURE FOR TASK IMPLEMENTATION CYCLE}

According to Christison and Murray $(2014,206)$, procedure or operations for task implementation cycle are pre-task, task completion and task review.

\section{Pre-task}

In the pre-task phase, students' attention should be on what will be expected of them during the task cycle. The lecturer could also prepare students with pertinent concepts and model the task (cf. Christison and Murray 2014, 206; see Appendix A). The lecturer takes students through the course outline expatiating on the content and the students' oral and written scheduled responsibilities. The students are also referred to the course pack which ideally phases them in into relevant L2 learning materials. They are also expected to use the library to augment sources they could use for preparing for their presentations.

\section{Task completion}

Students usually work in smaller groups to complete the task during the task completion phase. This implies that the lecturer's role is typically limited to a facilitator or observer (Christison and Murray 2014, 206). Since the number of graduate students in the course is manageable, 
they are scheduled to prepare presentations individually but are on average grouped into three per topic depending on the number of students registered for the course for a given year. Their different approaches reveal how rich content can be. They also make presentations even more interesting.

\section{Task review}

If completion of a task has resulted in an oral PowerPoint presentation, for example, students can critique one another's work and offer constructive feedback. Rubrics are also useful in this phase so that the students can determine whether they have achieved the set objectives or not. The lecturer can also, with input from learners, summarise what language students have learned during the task. Such a summary can help alleviate the anxiety of students who could be used to more traditional approaches (Christison and Murray 2014, 206). The SLA students would critique one another's input and offer constructive feedback during seminar presentations (see Appendix A)

\section{MOTIVATION}

Motivation could be interpreted as a state of cognitive and emotional arousal which develops to a conscious decision to act. It gives rise to a period of sustained intellectual and or physical effort in order to attain a previously set goal or goals (Williams and Burden 1997, 120). Thus, students need sustained intellectual as well as physical effort to attain set goals to pass this Honours degree.

Furthermore, students need to be aroused in some way. This could involve an element of desire; the initial arousal may be triggered by different causes. Some could be internal such as interest or curiosity or others external that are influences such as another person or event. The students' interest or enthusiasm could be activated, leading them to making conscious decisions to act in certain ways so as to achieve a particular goal related to the activity being undertaken. Therefore, the internal-external distinction plays a significant part in theories of motivation (Williams and Burden 1997, 120). In the same vein, SLA students need to be motivated to search for and read L2 materials thus leading to a period of sustained intellectual and physical effort resulting in them eventually presenting orally and in writing several times as per course schedule (see Appendix A).

Moreover, motivation is a highly complex phenomenon which is dynamic in nature; it is not something a learner has or does not have. Rather, it is something that varies from one moment to the next, that is governed by the learning context or task (Ellis 1997, 76). The learning context as well as tasks are varied as students perform different tasks scheduled for 
different presenters, on different dates. This is geared towards breaking the monotony in class.

Interpersonal relationships and social factors may serve to heighten or dampen particular affective states such as motivation and anxiety. This can in turn influence the degree to which the learner is able to attend to incoming input, process feedback, produce output and then benefit individually or collectively from in the L2 (Mackey 2012, 142). When students attend to input, produce output and process feedback at their disposal, they can benefit individually or collectively. These endeavours encapsulate what happens as they interact during performance of tasks every time they prepare and attend SLA course sessions. The students are also encouraged to share presentations already made with the rest of the group members.

Motivation is about the attitudes and affective states that influence the degree of effort learners make to learn an L2. It is thus currently regarded as a dynamic phenomenon among language learners (Richards, Ross and Seedhouse 2012, 29).

Ellis $(1994,715)$ asserts that motivation is dynamic rather than stable in that learners can become more or less motivated by their experiences of language learning. The construct of motivation is rather abstract and involves the effort which learners put into learning an L2 emanating from their need or desire to learn the language.

Learners are frequently surveyed about their motivation, attitudes, opinions or ability. However, learner confidence to perform language learning tasks is a common object of interest (Richards, Ross and Seedhouse 2012,166). This research article is about graduate students registered for a SLA course. These students are mostly L2 speakers of English in a multilingual South African university setting, by extension. They are also aware of the currency of English in their country.

According to Richards, Ross and Seedhouse (2012, 123), surveys about learner motivation and agency are particularly susceptible to social desirability, and usually need supporting evidence before further analysis can be carried out.

Learner identity is becoming an increasingly important research issue. It can either or not be related to a First Language (L1) speaker, motivation, successful students, beginners and cross-cultural communication (Richards, Ross and Seedhouse 2012, 217). These students are mostly English L2 speakers furthering studies at an English medium university.

Moreover, on searching the literature, the researcher observes that there are lots of studies of motivation, needs analysis, curriculum, teaching materials and teaching methods (Richards, Ross and Seedhouse 2012,10). However, none of the studies relate to the specific problems identified in my institution, UL. Hence the significance of scaffolding for ESLA students.

The reality of formal language learning is that a learning tasks would generally more often be introduced by the educator. Two main factors are significant in contributing to the learner's 
motivation to participate in task activities; the personality or nature of the person introducing the task and the way in which the educator presents the activity as well as works with the students during the completion of that activity. Thus, the role of the educator remains important throughout the motivational process (Williams and Burden 1997, 133). In this regard, the role of the ESLA lecturer is to a certain extent manifested in the performance of students (see Results).

Dynamic fluctuations in motivation during a task result from a response to a variety of cognitive, metacognitive and affective experiences related to a given context. The sequencing of task-related success or failure might be especially relevant to changing levels of motivation as a series of tasks unfolds over time (MacIntyre and Serroul 2015, 111).

Motivation is not static. It constantly increases or decreases depending on various social influences which may surround a student's action. It also refers to the student's appraisal of influences and action control operations he or she executes on such motivational content (Dornyei 2002, 156). Thus, these ambivalent situations which are tolerated and expected by students do occur in SLA (MacIntyre and Serroul 2015, 113).

MacIntyre and Serroul $(2015,114)$ argue that adopting a dynamic perspective allows practitioners to draw the concept of motivation closer to a key cognitive process: deciding what to say and how to say it; this underlies communication.

A further aspect of the role of the lecturer in motivation is providing feedback. It can be given through praise, by any relevant comment or action, or silence. Any action, or lack thereof, by another significant person, may be interpreted as a form of feedback. Implicitly, feedback is in a broader area of reinforcement (Williams and Burden 1997, 134). The lecturer gives regular and prompt feedback in session after presentations while the one on written presentations is given in subsequent sessions. These are meant to reinforce students' contributions.

If the ongoing assessment of competence during a communication event is considered in conjunction with the action assembly process, research could be better positioned to examine the links between communicative performance on the one hand and dynamic perceptions of approach/avoidance motivation, that could rise and fall, on the other hand (cf. MacIntyre and Serroul 2015, 114; see Results).

Motivation theories mainly deal with factors which are internal to the student. These include a sense of agency, locus of control, locus of causality, effectiveness motivation and motivational style.

\section{A sense of agency}

A number of researchers investigating cognitive approaches to motivation regard the sense 
people have of whether they are responsible for and are in control of their actions or whether they perceive what happens to them as being controlled by other people as an important determinant in motivation. These factors are partly what is called a "sense of agency" (Williams and Burden 1997, 127). Thus, this "sense of agency" could be accepted as an important determinant in motivating people to behave in certain ways (Williams and Burden 1997, 128). The lecturer strives to inculcate a sense of agency in students in the sense that they are in control of their actions in the course.

\section{Locus of causality}

The notion of causality accounts for whether people regard themselves or others as the cause of their actions. People who regard themselves as largely responsible for originating their own actions are termed "origins", while those who see other people as causing what happens to them are known as pawns (De Charms 1984). In line with this, students need to see themselves more as "origins" rather than "pawns".

\section{Locus of control}

Locus control refers to whether people are subsequently in control of their actions. The extent to which students are in control of their learning of a language will have an effect on their motivation to be continually involved in learning the language (Williams and Burden 1997, 128). It is envisaged that under the guidance of the lecturer, the ESLA learning environment will eventually bring students closer to taking control of the learning.

Setting appropriate goals is an essential part of motivated behaviour to an extent that decisions can be carried out and the necessary effort sustained (Williams and Burden 1997, 131).

Furthermore, Williams and Burden $(1997,120)$ state that goals may be within the activity itself, or an activity may be undertaken because it is a means to another end. Once the activity has begun, the student needs to sustain the effort needed to achieve the goal through persistence. All this is influenced by the context and situation, and remains personal.

Moreover, Richards, Ross and Seedhouse $(2012,136)$ maintain that motivation, attitudes towards the language being learnt and its speakers, willingness to communicate and personality are included among affective factors in second language research.

\section{Kinds of motivation}

There are various kinds of motivation. These are instrumental, integrative, resultative as well as intrinsic motivation (Ellis 1997, 75). However, these four types of motivation should be 
perceived as complementary rather than distinct and oppositional (Ellis 1997, 76).

\section{Instrumental motivation}

Some learners may make efforts to learn an L2 for some functional reason such as passing an examination, getting a better job, or admission at a university. Thus, instrumental motivation could be the major force which determines success in L2 learning (Ellis 1997, 75). The currency of English language in Higher Education together with its hegemony in South Africa does motivate SLA students to work harder.

\section{Integrative motivation}

Other students may choose to learn a particular L2 because of their interest in the people and culture represented by the target-language group (Ellis 1997, 75). SLA post-graduate students need to be motivated more because the number of English native speakers at UL is negligible.

\section{Resultative motivation}

Resultative motivation research assumes that motivation causes L2 achievement. It is, however, possible that motivation could result from learning. This implies that students who experience success in learning tend to be more or in some contexts, less motivated to continue learning (Ellis 1997, 75). Some students in the course would like to seek employment while others are eager to proceed to Master's level.

\section{Intrinsic motivation}

Learners could find the kinds of learning tasks they are asked to perform intrinsically motivating. In line with this, motivation involves the arousal as well as the sustenance of curiosity which can fluctuate, as a result of factors such as learners' particular interests and the degree to which they feel personally ready to participate in learning activities (Ellis 1997, 76). The course lecturer strives to sustain a constant flow of motivation within and without contact sessions.

Intrinsic motivation is boosted by culturally familiar content; if the materials students are exposed to serve the dual goals of being friendly in a South African way and cater for the culture of the classroom (cf. Tomlinson and Masuhara 2004, 19). In their illustrations during oral and written presentations, students adapt the materials they use to a culturally relevant South African context. This is apparent in the illustrations they make. 


\section{AGENCY}

Agency is learners' socio-culturally mediated right to opt whether to partake in a communication and in what language. Agency is also associated with learners' available linguistic resources and their desire to participate in constitutive and discursive interactions (Baynham 2006; Collins 1993; Miller 2012). There is, therefore, agency among the students to take part and interact in the course. There is also a course pack, other relevant materials as well as peers to carry students through their SLA endeavours.

In the field of SLA, context does guide people to discern how social settings encourage individuals to learn and use an L2 (Duran 2015, 78).

The desire to participate could be understood as learners' willingness to communicate which is some self-selected practice. When students have a desire to participate, they are likely to use the target language to engage in the communication they deem fit, voluntarily (Duran 2015, 79).

Numerous factors encourage students' readiness to enter into a communicative discourse. These grant students agency in language learning, collaboratively. The specific person or group of people represents members of a community which has an impact on the individual's decision-making. The desire to participate could be understood as students' willingness to communicate; this is about self-selected practice (Duran 2015, 79).

In addition, learning a second or additional language could be associated strongly with internally or externally imposed instrumental motivation. A student's future economic or social mobility may depend on his or her success or failure to exert his or her agency by becoming part of a given target language speech community (Duff et al. 2013, 117). Thus, English SLA students belong to the English language community at the heart of knowledge construction (see Methodology).

Some vigorous linguistic practices indicate that learners' language-learning trajectories get complicated because of multiple settings they are exposed. These could be attributed to the rapid flows of people across cultural and linguistic borders, particularly in the last few decades (Duran 2015, 74).

In the field of SLA, context can guide lecturers to interpret how social settings encourage individuals to learn and use an L2, emphasizing students' participation in the language learning process and engagement in communities of practice (Duran 2015, 78). The graduate students are registered in the UL English Language Studies (ELS) community; they practise and interact with the lecturers and peers.

The desire to participate, mentioned above, can be understood as learners' willingness to communicate, which is a self-selected practice. Many factors such as linguistic knowledge and 
communicative competence would encourage learners' readiness to enter into a communicative discourse (MacIntyre et al. 1998, 547). The English language lecturer arouses the students' willingness to prepare for and participate in presentations. The SLA learning environment supports students in their endeavour to participate through kick-start sessions such as arranging for library sessions and compiling the course pack.

When there is agency, learners are more likely to voluntarily communicate where they deem it fit (Duran 2015, 79). As a result, students are willing and motivated to participate in order to score good marks which would serve as a formative mark building towards a summative one, for a given year of study.

\section{KEY PRINCIPLES MOTIVATING CHANGES TO MATERIAL}

Key principles motivating changes to the materials are personalisation, localisation, and language for communicative purposes.

\section{Personalisation}

The principle of personalisation draws on learners' lives and exploits their knowledge and interests to devise examples and activities which are about them. This principle is linked to the learner's profile as it is amenable to the integration of technology into the learning environment (Liton 2012, 147). This principle is also relevant to teaching SLA graduate students. For, example, personalisation affords students an opportunity to tap on their life experiences, knowledge and interests as they integrate technology to provide pertinent examples during presentations.

\section{Localisation}

Mcgrath $(2002,74)$ defines localisation as recognising the need for contextual relevance'. This should fit with the learner's profile and more broadly with the need to localise material content considering geographical and cultural identity, for example. The English SLA student profile indicates that a few, if any, students travelled outside South Africa. Thus, the L2 materials used have limited contextual relevance for these students and as a result, do not exploit the students' sense of nationalism.

In addition, Benjamin $(2015,30)$ asserts that changes made to the materials include attempting to incorporate more readily identifiable content. For instance, the course lecturer encourages students to adapt their L2 learning materials by providing illustrations from their knowledge and interests relevant to the South African context. The students are also encouraged to share presented content with rest of the ESLA students who would normally be part of an 
audience during oral presentations.

\section{Language for communicative purposes}

Students need opportunities to communicate in the target language. By providing scaffolding in the language presented, this activity could act as a development activity which helps students express what they have learnt from the readings using the target language (Tomlinson 2010, 10). The SLA course scaffolded developmental tasks are actualised through seminar oral- and written presentations in English. These tasks are prepared from the ESLA course pack and other additional sources sought by the students themselves (see Appendix A).

\section{DYNAMIC SYSTEMS}

Research in applied linguistics on the description and investigation of various constructs which serve as interrelated - and interconnected parts of complex Dynamic Systems (DSs), has recently gained ground (Piniel and Csizer 2015, 164).

Scholars advocating a DS approach in SLA research have listed some of the following fundamental features: sensitive dependence on initial conditions, interconnectedness, nonlinear development, emergent characteristics, intra-individual variation, inter-individual variation, dependence on internal as well as external resources and change owing to interaction with the environment and internal re-organization (Piniel and Csizer 2015, 165). Hence, the ESLA study which deals with tasks, motivation, agency and L2 materials.

These characteristics suggest that language learning studies in Individual Differences (IDs) from a DS perspective necessitate the study of the interrelationship(s) of variables (Piniel and Csizer 2015, 165).

To this end, much of the literature on IDs in SLA isolate variables such as anxiety, beliefs, cognitive abilities, learning strategies, willingness to communicate and motivation (Robinson 2012). However, from a dynamic perspective, the term "variables" takes on an expended meaning which reflects any influence on the ongoing process of a system. References to variables in the system include familiar, traditional individual differences pertaining to motivation, anxiety or aptitude. Changeable features of the context such as the behaviour of the lecturer and classmates, progress made during the lecture plan or changing demographics in the community are also included. These are in a perpetual state of flux and often result in emergent, non-linear, unpredictable outcomes. If the complexity apparent within each individual is impressive, how much more could the dynamism among individuals grouped in a communicative process be (cf. Gregersen and MacIntyre 2015, 263; see Results).

The present study uses complex dynamic systems (CDS) theory to interpret the 
motivational processes described in in the performance of ESLA graduate students (cf. Gregersen and MacIntyre 2015, 260; see Results).

\section{AN OVERVIEW OF THE ESLA COURSE}

The UL ESLA course is a full time one year Honours course. An overview of this course comprises contact sessions, approach and assessment.

\section{Contact sessions}

Contact sessions with students could be geared towards the students' immediate and known needs. However, one of the disadvantages is that some of the students are likely to be at a lower language proficiency level (Jordan 1997, 70). For example, most SLA students need more support as they shall not have been immersed in an English language community from the outset. In line with the IDs of the students, the contact sessions are run fortnightly while students are scheduled to take part in seminars as per their pre-assigned responsibilities.

Students take part in seminars, in blocks of two hours, fortnightly. They sit for an examination which is validated by external examiners.

Most long, full-time courses have some problems with sustaining interest and motivation over a long period (Jordan 1997, 71). The number of students attending this long ESLA course is relatively smaller than the number attending short courses; the maximum number to date is 20 (cf. Jordan 1997, 72). ESLA course is a year course made up of an average of twelve contact session in a year.

Since there is more time to develop different components in the syllabus, the pace can be slower, allowing the lecturer to devote more time to individualised help. Thus, closer rapport can be built between the lecturer and students (cf. Jordan 1997, 72; see Course Outline).

\section{Seminar approach}

A seminar approach is mainly employed for learning and assessing the course. The lecturer compiles an L2 course pack for students. They are encouraged to augment the materials provided in the course pack with other relevant material which could serve the purpose. The materials used should feature and be acknowledged in their presentations as well as assignments.

Generally, seminars are meetings with a lecturer and a fairly small group of 20 students (Hyland 2006, 14). Not all universities and departments use the phrase "seminar presentation" in the same way. In a seminar, a student may lead a discussion (Hyland 2006, 15).

Students benefit from participating in the discussion and for some courses, part of their 
final assessment might come from their involvement in seminars. But if students are not, seminar discussions give one a chance to ask for explanations, to check their ideas and to hear other opinions; those of the lecturer and other students (Hyland 2006, 16).

ESLA tasks for the students are in the form of oral presentations and written tasks. Students prepare oral presentations and written assignments on given topics annually while peers are expected to prepare on the side lines in anticipation to participate in the review of each presentation. This is meant to trigger enriching class discussions and interaction as they ask questions, seek clarification and comment on the content of the presentation. Each oral presentation is allotted an average of 30 minutes. The lecturer facilitates and ensures the sustenance of interaction during contact sessions.

\section{Assessment}

Assessment tasks form part of a wider network of influences such as the nature of the curriculum as well as the discipline, teachers' beliefs and aims, the educational and institutional context, relationships between classroom participants, students' attitudes and motivations towards the course being studied and the extent to which students are focused on grades and mastery of relevant content or skills (Carless 2015, 48)

The idea of learning oriented assessment is that all assessments should support the advancement of student learning (Carless 2015, 6). Hence, the use of L2 learning materials and formative assessment of oral presentations as well as written assignments in this article.

Students' presentations are assessed orally and in writing through assessment grids developed by the lecturer while students interact during assessment of presentations by seeking clarification, adding to the input, making comments and so on (see Appendices B and C).

In addition, longer courses have more time and opportunity for formative assessment. This implies that feedback is provided by the students and the lecturer at various stages during the course. This also enables the ensuing parts of the course to be modified. There is, however, summative evaluation at the end (Jordan 1997, 73). Since the lecturer and students participate in assessing the oral work formatively during presentations, students are guaranteed language development from such interaction. It is against this background that Ngoepe $(2017,172)$ asserts that if lecturers and students assess in concert, students stand to benefit more. Thus, ESLA students benefit from these formative interactive experiences, by extension.

The course is assessed several times formatively and culminate in summative assessment towards the end of each academic year. ESLA summative assessment question papers are validated externally by other institutions of higher learning in South Africa. 


\section{METHODOLOGY}

The research design in this article is premised on some exploratory constructivism.

An exploratory design is relevant for this study because it would be effective for exploring this unchartered area (Dornyei 2007, 308) of ESLA through L2 materials. Little is known about this phenomena (Dornyei 2007, 39). Thus, motivating ESLA graduate students to perform tasks through L2 materials remains phenomenal.

On the other hand, in line with constructivism, students generate and acquire English Second Language (ESL) knowledge through L2 materials as they perform tasks (cf. Richards, Ross and Seedhouse 2012, 308).

Furthermore, Social Constructivism (SC) is about the intellectual climate in which academics live and work. This is about the intellectual climate in which ESLA students and the lecturer perform given tasks through L2 materials. It further determines problems students seek to investigate, the methods they use, the results they get and the way they write them up. Appropriate academic speaking and writing implies projecting a shared ESL context, as students would have become more sensitive to the ways the target language is used by individuals acting in social groups (Hyland 2006, 40). Students manifest a shared context in which they perform tasks through L2 learning materials.

In addition, SC refers to the agreement of academic community members at the heart of knowledge construction, and the specific language used to reach agreement as the success of both students as well as academics (Hyland 2006, 40). Similarly, ESLA students are at the heart of knowledge construction in English language learning. They also constitute a group of likeminded English language disciplinary community. Hence, it is against this background that Hyland $(2006,41)$ corroborates that the idea of a disciplinary community suggests a relatively heterogenous group of like-minded individuals. The students constitute a group of like-minded SLA English language disciplinary community that constructs knowledge through oral and written presentations.

\section{RESULTS}

In this section, scores for ESLA tasks performed by the students during the period 2012 to 2014 are analysed. The highest possible score per presentation is 25 . These scores comprise 2 oral presentations and 2 assignments per student, per semester. The scores are further subsumed under one SLA group average scores per annum, for the period under review. Thus, the scores are presented in 3 Figures and a Table. 


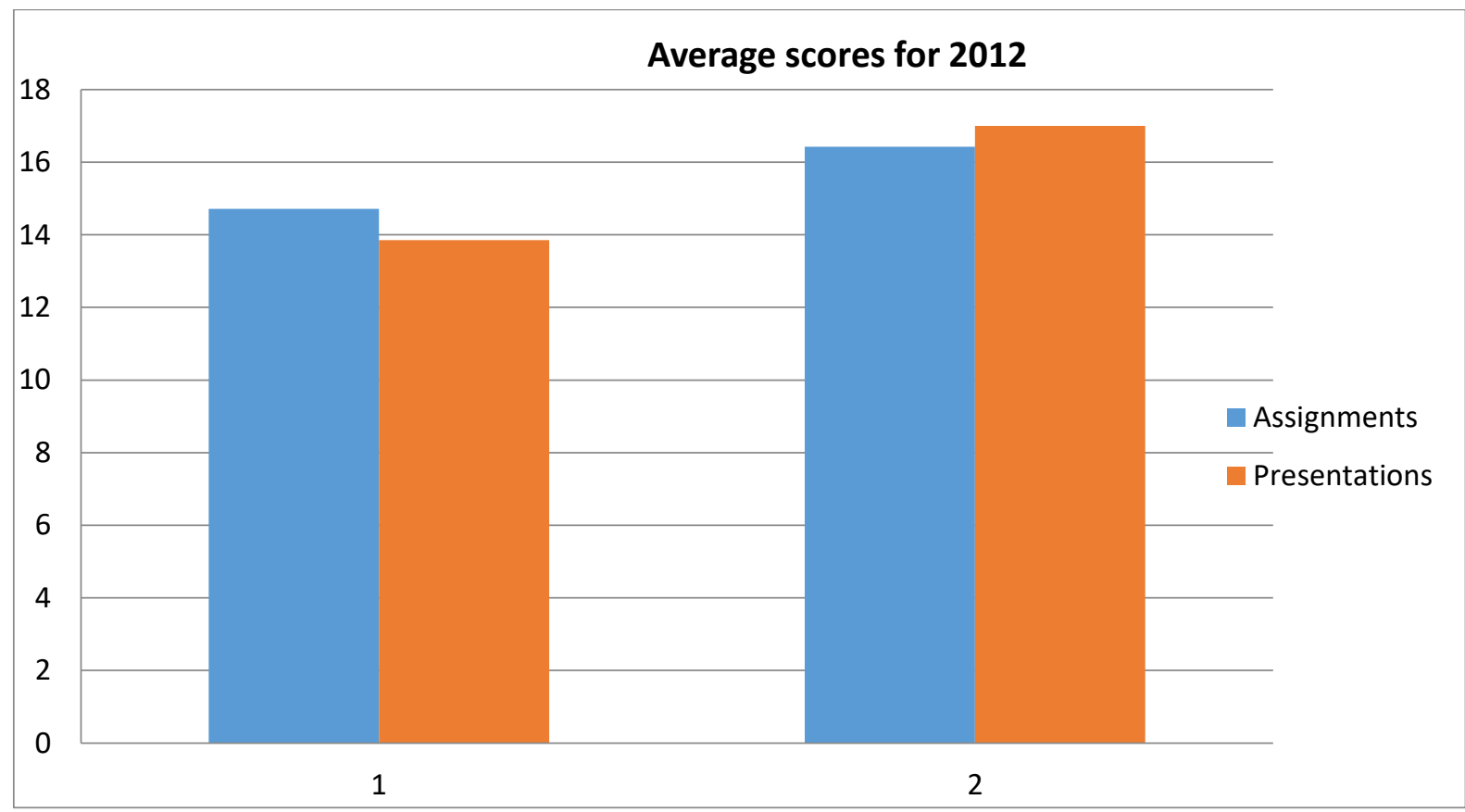

Figure 1: Group average scores of written assignments and oral presentations for 2012

Figure 1 presents group average scores for both written assignments and oral presentations for the first and second semester. Student scores for written assignments are slightly higher than that in oral presentations in the first semester while the opposite is the case in the second semester. However, these scores are relatively high in the second semester.

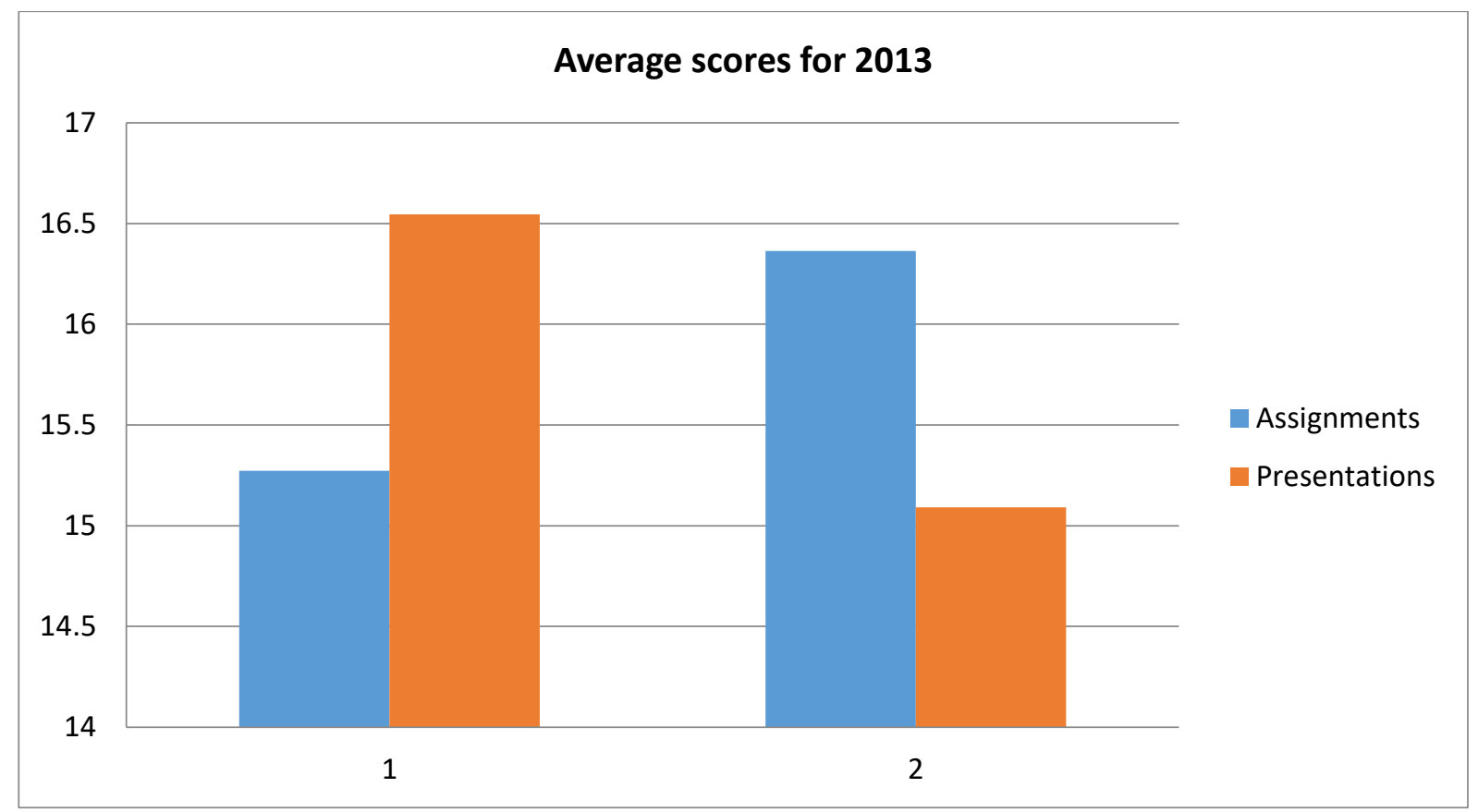

Figure 2: Group average scores of written assignments and oral presentations for 2013

In Figure 2, group average scores for written assignments are relatively low compared to oral 
presentations in the period under review in the first semester. In the second semester, the average scores for written assignments are higher than those of oral presentations.

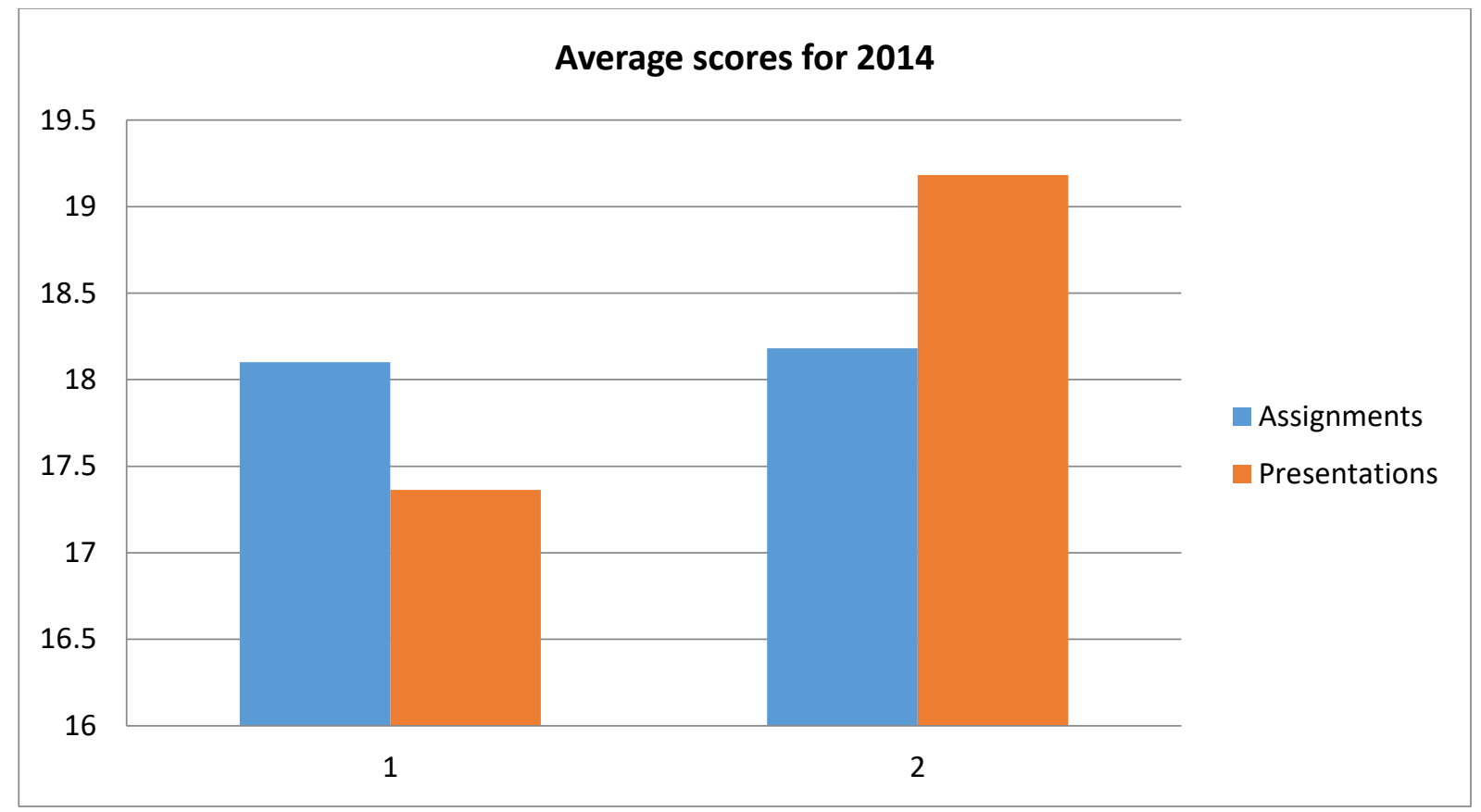

Figure 3: Group average scores of written assignments and oral presentations for 2014

Written assignment group average scores depicted in Figure 3, in the first semester, are higher than the oral presentation ones. In the second semester, however, written assignment scores were slightly lower than the oral presentation ones.

Table 1: Group annual averages of SLA graduate students

\begin{tabular}{|l|l|l|}
\hline Year & No. of Students & Average \\
\hline 2012 & 7 & 59.7 \\
\hline 2013 & 14 & 63.5 \\
\hline 2014 & 13 & 71 \\
\hline
\end{tabular}

The number of students registered for the course almost doubled during the period under review. On the whole, group average scores are somewhat erratic. The scores increased slightly by about 4 per cent between the years 2012 and 2013. But they increased by close to 7 per cent between the years 2013 and 2014.

Although the score averages increased exponentially over the period under review, there is an overall inconsistent performance of students over the three years. 


\section{DISCUSSION}

Students make the most of oral and written formative tasks. There is, on the whole, a sustenance of task motivation over the period under review.

Planned task motivation inadvertently encourages graduate students to perform consistently; initially with relatively much support from their lecturer followed by them being purposefully and gradually weaned from that support, leading to independent study in the long term. This planning is corroborated by the lecturer's, together with the graduates' part taking in pre-task, task completion and task review of the course, piecemeal.

Social constructivism is at the heart of exploring planned English language task motivation implementation; students create knowledge in unison, albeit through different roles captured in the course outline and led by the catalytic role played by their lecturer, in a shared context. Thus, students are given space to try their wings interactively in an English discipline community environment, using L2 learning materials.

Graduate students remain motivated to perform tasks successfully through L2 materials in the short term while their ESLA knowledge is enriched by the overall experience in the long term.

The seminar approach is meant to trigger student agency to use L2 materials as well as sustain their essential motivation levels when preparing for presentations.

That the lecturer employs the DSs approach implies that students' IDs are taken into consideration in the planning and implementation of the ESLA course.

Students do augment the in-house L2 course pack materials in the task implementation process. As a result, their physical and intellectual efforts are sustained (see Results).

As students perform tasks, they attempt to make sense of the English L2 materials. They also personalise and localise the materials at their disposal. However, they have agency to participate in activities outlined (see Appendix A).

The erratic average scores of students over the period under review illustrate the dynamic nature of task motivation. The overall trend depicts successful academic speaking and writing, in context. Thus, students have some sense of agency, locus of causality and locus of control over their tasks.

\section{CONCLUSION}

Since the ESLA course is mainly patronised by students who have potential to succeed at postgraduate level, relatively more academic support from the learning environment is arguably needed by the students when joining the English Language Studies (ELS) fraternity.

Opting to follow a DSs approach affords the lecturer an opportunity to accentuate the 
students' variables as reflected in their IDs. These could further be exploited to the very students' collective benefit.

Due to the currency of English in South Africa, scaffolding is essential to ESLA students who are admitted and retained in ELS. They, however, need some scaffolding in order to succeed annually.

Since the English is used as a medium of instruction in most institutions of higher learning in South Africa, including UL, this places a premium on English language proficiency more especially for graduate English language students.

\section{REFERENCES}

Abu-Rabia, S. 2003. Cognitive and social factors affecting Arab students learning English as a third language in Israel. Educational Psychology 23(4): 347-360.

Baynham, M. J. 2006. Agency and contingency in the language learning of refugees and asylum seekers. Linguistics and Education 17(1): 24-39.

Benjamin, P. 2015. Cultural appropriacy in materials adaptation: Do we need to walk on eggshells? Folio 16(2): 30-35.

Carless, D. 2015. Excellence in university assessment. Routledge: London.

Christison, M. and D. E. Murray. 2014. What English language teachers need to know. Volume III: Designing curriculum. Routledge: New York.

Collins, J. 1993. Determination and contradiction: An appreciation and critique of the work of Pierre Bourdieu on language and education. In Critical perspectives, ed. C. Calhoun, E. Lipuma and M. Postone, (116-138). Bourdieu: Cambridge: Polity Press.

De Charms, R. 1984. Motivation enhancement in educational settings. In Research on motivation in education. Vol. 1: Student motivation, ed. C. Ames and R. E. Ames. New York: Academic Press.

Dornyei, Z. 2002. The motivational basis of language learning tasks. In Individual differences and instructed language learning, ed. P. Robinson. Amsterdam: Benjamin Publishing Company.

Dornyei, Z. 2007. Research methods in applied linguistics. Oxford: Oxford University Press.

Duff, P., T. Anderson, R. IInyckyj, E. van Gaya, R. Wany and E. Yates. 2013. Learning Chinese: Linguistic, sociocultural and narrative perspectives. Berlin/Boston: De Gruyter.

Duran, C. S. 2015. Theorizing young language learner agency through the lens of multilingual repertoires: A sociocultural perspective. In Theorizing and analysing agency in second language learning: Interdisciplinary approaches, ed. P. Deters, X. A. Gao, E. R. Miller and G. Vitanova. Bristol: Multilingual Matters.

Ellis, R. 1994. The study of second language acquisition. Oxford: Oxford University Press.

Ellis, R. 1997. Second language acquisition. Oxford: Oxford University Press.

Ellis, R. 2011. Macro- and micro-evaluations of task-based teaching. In Materials development in language teaching, ed. B. Tomlinson. $2^{\text {nd }}$ Edition. Cambridge: Cambridge University Press.

Gregersen, T. and P. D. MacIntyre. 2015. "I can see a little bit of you on myself": A dynamic systems approach to the inner dialogue between teacher and learner selves. In Motivational dynamics in Language learning, ed. Z. Dornyei, P. D. MacIntyre. Bristol: Multilingual Matters.

Hyland, K. 2006. English for academic purposes: An advanced resource book. London: Routledge.

Jordan, R. R. 1997. English for academic purposes: A guide and resource book for teachers. Cambridge: Cambridge University Press. 
Liton, H. A. 2012. Developing EFL teaching and learning practices in Saudi colleges: A review. International Journal of Instruction 5(2): 129-152.

MacIntyre, P. D., R. Clement, Z. Dornyei and K. A. Noels. 1998. Conceptualizing willingness to communicate in a L2: A situational model of L2 confidence and affiliation. The Modern Language Journal 82(4): 545-562.

MacIntyre, P. D. and A. Serroul. 2015. Motivation on a per-second timescale: Examining approachavoidance motivation during L2 task performance. In Motivational dynamics in language learning, ed. Z. Dornyei, P. D. MacIntyre and A. Henry. Bristol: Multilingual Matters.

Mackey, A. 2012. Interaction, and corrective feedback in L2 learning. Oxford: Oxford University Press.

McDonough, J., C. Shaw and H. Masuhara. 2013. Materials and methods in ELT: A teacher's guide. $3^{\text {rd }}$ Edition. Oxford: Wiley - Blackwell.

McGrath, I. 2002. Materials evaluation and design for language teaching. Edinburgh: Edinburgh University Press.

Miller, E. R. 2012. Agency, language learning, and multilingual spaces. Multilingua 31(4): 441-468.

Ngoepe, L. J. 2017. Ethnographically oriented assessment of an emergent multidisciplinary science ESP group project module. South African Journal of HigherEducation 31(2): 172-191.

Piniel, K. and K. Csizer. 2015. Changes in motivation, anxiety, and self-efficacy during the course of an academic writing seminar. In Motivational dynamics in language learning, ed. Z. Dornyei, P. D. MacIntyre and A. Henry. Bristol: Multilingual Matters.

Pica, T. 2005. Classroom learning, teaching and research: A task-based perspective. The Modern Language Journal 89(3): 339-352.

Richards, K., S. Ross and P. Seedhouse. 2012. Research methods for applied language studies: An advanced resource book for students. London: Routledge London.

Robinson, P. 2012. The Routledge Encyclopedia for Second Language Acquisition. New York: Routledge.

Tasseron, M. 2015. These materials work and learners agree! Folio 16(2): 22-28.

Tomlinson, B. and H. Masuhara. 2004. Activities for cultural awareness. Folio 9(1): 19-23.

Tomlinson, B. 2010. Principles and procedures of materials development for language learning (Part 2). Folio 14(2): 9-11.

Williams, M. and R. L. Burden. 1997. Psychology for language teachers: A social constructivist approach. Cambridge: Cambridge University Press. 


\section{APPENDICES}

\section{Appendix A: Sample SLA course outline}

\section{English Second Language Acquisition (ESLA)}

English Second Language Acquisition is a year course which is outlined as follows:

\begin{tabular}{|c|c|c|c|c|}
\hline Date & Theme & Unit Outcomes & Assessment Task(s) & Presenter(s) \\
\hline Week 1: 11 February & $\begin{array}{ll}\text { 1. Introduction to } \\
\text { SLA }\end{array}$ & $\begin{array}{l}\text { To contextualise } \\
\text { English SLA }\end{array}$ & $\begin{array}{l}\text { A discussion of English } \\
\text { SLA led by lecturer }\end{array}$ & All \\
\hline Week 2: 25 February & $\begin{array}{l}\text { 2. Behaviourist \& } \\
\text { Mentalist } \\
\text { theories of } \\
\text { Language } \\
\text { Learning }\end{array}$ & $\begin{array}{l}\text { To outline the } \\
\text { complementary } \\
\text { roles of the } \\
\text { Behaviourist and } \\
\text { Mentalist theories in } \\
\text { SLA }\end{array}$ & $\begin{array}{l}\text { Outline the } \\
\text { complementary process } \\
\text { of the Behaviourist \& } \\
\text { Mentalist theories }\end{array}$ & Student (s) \\
\hline Week 3: 10 March & 3. Interlanguage & $\begin{array}{l}\text { To discuss learner } \\
\text { language in the } \\
\text { process of SLA }\end{array}$ & $\begin{array}{l}\text { Discuss learner } \\
\text { language in the process } \\
\text { of SLA }\end{array}$ & Student (s) \\
\hline Week 4: 7 April & $\begin{array}{l}\text { 4. The Role of } \\
\text { the First } \\
\text { Language in } \\
\text { SLA }\end{array}$ & $\begin{array}{l}\text { To describe how } \\
\text { SLA is influenced } \\
\text { by } L 1\end{array}$ & $\begin{array}{l}\text { Describe how SLA is } \\
\text { influenced by L1 }\end{array}$ & Student (s) \\
\hline Week 5: 21 April & $\begin{array}{l}\text { 5. Errors \& Error } \\
\text { Analysis }\end{array}$ & $\begin{array}{l}\text { To distinguish } \\
\text { between learners' } \\
\text { mistakes \& errors }\end{array}$ & $\begin{array}{l}\text { Distinguish between } \\
\text { learners' mistakes \& } \\
\text { errors }\end{array}$ & Student (s) \\
\hline Week 6: 9 May & $\begin{array}{l}\text { 6. The theory of } \\
\text { Universal } \\
\text { Grammar (UG) }\end{array}$ & $\begin{array}{l}\text { To provide } \\
\text { Chomsky's primary } \\
\text { justification for } \\
\text { Universal Grammar }\end{array}$ & $\begin{array}{l}\text { Provide Chomsky's } \\
\text { primary justification for } \\
\text { Universal Grammar }\end{array}$ & Student (s) \\
\hline Week 7: 14 July & $\begin{array}{l}\text { 7. The Role of } \\
\text { Formal } \\
\text { Instruction in } \\
\text { SLA }\end{array}$ & $\begin{array}{l}\text { To synthesise } \\
\text { purposes of formal } \\
\text { instruction }\end{array}$ & $\begin{array}{l}\text { Synthesise the } \\
\text { purposes of formal } \\
\text { instruction }\end{array}$ & Student (s) \\
\hline Week 8: 28 July & $\begin{array}{l}\text { 8. Social Identity } \\
\text { and } \\
\text { Investment in } \\
\text { L2 }\end{array}$ & $\begin{array}{l}\text { To outline Social } \\
\text { Identity and } \\
\text { Investment in L2 }\end{array}$ & $\begin{array}{l}\text { Outline Social Identity } \\
\text { and Investment in L2 }\end{array}$ & Student(s) \\
\hline Week 9: 11 August & $\begin{array}{ll}\text { 9. } & \text { Interaction- } \\
\text { driven L2 } \\
\text { Learning }\end{array}$ & $\begin{array}{l}\text { To discuss } \\
\text { interaction-driven } \\
\text { L2 learning }\end{array}$ & $\begin{array}{l}\text { Discuss interaction- } \\
\text { driven L2 learning }\end{array}$ & $\begin{array}{l}\text { Student(s) \& } \\
\text { Assignment (s) }\end{array}$ \\
\hline Week 10: 25 August & $\begin{array}{l}\text { 10. Individual } \\
\text { Learner } \\
\text { Differences in } \\
\text { SLA }\end{array}$ & $\begin{array}{l}\text { To describe how } \\
\text { individual learner } \\
\text { differences affect } \\
\text { SLA }\end{array}$ & $\begin{array}{l}\text { Describe how individual } \\
\text { learner differences } \\
\text { affect SLA }\end{array}$ & Student (s) \\
\hline $\begin{array}{l}\text { Week 11: } 8 \\
\text { September }\end{array}$ & 11. Motivation & $\begin{array}{l}\text { To discuss } \\
\text { motivation in the } \\
\text { context of SLA }\end{array}$ & $\begin{array}{l}\text { Discuss motivation in } \\
\text { the context of SLA }\end{array}$ & Student (s) \\
\hline $\begin{array}{l}\text { Week 12: } 29 \\
\text { September }\end{array}$ & $\begin{array}{l}\text { 12. SLA Learning } \\
\text { Strategies }\end{array}$ & $\begin{array}{l}\text { To outline strategies } \\
\text { that L2 learners } \\
\text { employ }\end{array}$ & $\begin{array}{l}\text { Outline strategies that } \\
\text { L2 learners employ }\end{array}$ & Student (s) \\
\hline Week 13: 13 October & $\begin{array}{l}\text { 13. Future } \\
\text { Directions for } \\
\text { Second } \\
\text { Language } \\
\text { Research }\end{array}$ & $\begin{array}{l}\text { To identify possible } \\
\text { research topics } \\
\text { from the SLA } \\
\text { themes studied }\end{array}$ & $\begin{array}{l}\text { Identify possible } \\
\text { research topics from the } \\
\text { SLA themes studied }\end{array}$ & All \\
\hline
\end{tabular}

\section{Teaching Approach}

A seminar approach is followed. Students prepare presentations on given topics. These presentations are assessed during contact sessions; they are meant to trigger some enriching class discussion and interaction. The lecturer facilitates and ensures the sustenance of class interaction. 


\section{Formative Assessment}

Assessment consists of at least two presentations and two written assignments per annum. Each of these will be marked out of 25 .

\section{Summative assessment}

Students sit for a written examination at the end of the 2016 academic year (see Important Dates)

\section{Year Mark}

The year mark is made up of at least 2 presentations and 2 assignments.

\section{Final Mark}

The average of the year mark and the examination mark equals a student's final mark.

\section{List of Recommended Books}

1. Alderson, C. 2009. The politics of language education: Individuals and institutions. Bristol: Multilingual Matters.

2. Dornyei, Z. and E. Ushioda. 2009. Motivation, language identity and the L2 self. Bristol: Multilingual Matters.

3. Ellis, R. 1997. Second language acquisition. Oxford: Oxford University Press.

4. Ellis, R. 1986. Understanding second language acquisition. Oxford: Oxford University Press.

5. Mitchell, R. and F. Myles. 2004. Second language learning theories. Second Edition. New York: Hodder Arnold.

6. Saville-Troike, M. 2006. Introducing second language acquisition. Cambridge: Cambridge University Press.

\section{Appendix B: Assessment grid for oral presentations}

The breakdown of marks to be allocated during oral presentations is as follows:

\begin{tabular}{|l|l|l|}
\hline Aspect & Possible Score & Actual Score \\
\hline Content & 10 & \\
\hline Various Sources Referenced & 8 & \\
\hline Structure & 5 & \\
\hline Deportment & 2 & \\
\hline Total & 25 & \\
\hline
\end{tabular}

\section{Appendix C: Assessment grid for written presentations}

The breakdown of marks to be allocated during written presentations is as follows:

\begin{tabular}{|l|l|l|}
\hline Aspect & Possible Score & Actual Score \\
\hline Content & 10 & \\
\hline In-text referencing & 8 & \\
\hline Structure & 2 & \\
\hline References Bibliography & 5 & \\
\hline Total & 25 & \\
\hline
\end{tabular}

